\title{
An evaluation of heat on protein oxidation of soy protein isolate or soy protein isolate mixed with soybean oil in vitro and its consequences on redox status of broilers at early age
}

\author{
Xianglun Zhang ${ }^{1}$, Peng Lu', Wenyue Xue ${ }^{1}$, Dawei $\mathbf{W u}^{1}$, Chao Wen ${ }^{1}$, and Yanmin Zhou ${ }^{1, *}$
}

\section{* Corresponding Author: Yanmin Zhou Tel: +86-025-84396067, Fax: +86-025-84395314, E-mail: zhouym6308@163.com}

'College of Animal Science and Technology, Nanjing Agricultural University, Nanjing, Jiangsu 210095, China

Submitted Sept 11, 2016; Revised Dec 8, 2016; Accepted Jan 8, 2017
Objective: The objective of this study was to evaluate effects of heat treatment and soybean oil inclusion on protein oxidation of soy protein isolate (SPI) and of oxidized protein on redox status of broilers at an early age.

Methods: SPI mixed with soybean oil (SPIO) heated at $100^{\circ} \mathrm{C}$ for $8 \mathrm{~h}$ was used to evaluate protein oxidation of SPI. A total of two hundred and sixteen 1-day-old Arbor Acres chicks were divided into 3 groups with 6 replicates of 12 birds, receiving basal diet (CON), heat-oxidized SPI diet (HSPI) or mixture of SPI and 2\% soybean oil diet (HSPIO) for $21 \mathrm{~d}$, respectively. Results: Increased protein carbonyl, decreased protein sulfhydryl of SPI were observed as heating time increased in all treatments $(\mathrm{p}<0.05)$. Addition of $2 \%$ soybean oil increased protein carbonyl of SPI at $8 \mathrm{~h}$ heating $(\mathrm{p}<0.05)$. Dietary HSPI and HSPIO decreased the average daily gain of broilers as compared with the CON $(\mathrm{p}<0.05)$. Broilers fed HSPI and HSPIO exhibited decreased glutathione (GSH) in serum, catalase activity and total sulfhydryl in liver and increased malondialdehyde (MDA) and protein carbonyl in serum, advanced oxidation protein products (AOPPs) in liver and protein carbonyl in jejunal mucosa as compared with that of the CON $(\mathrm{p}<0.05)$. Additionally, broilers receiving HSPIO showed decreased glutathione peroxidase activity (GSH-Px) in serum, GSH and hydroxyl radical scavenging capacity in liver, GSH-Px activity in duodenal mucosa, GSH-Px activity and superoxide anion radical scavenging capacity in jejunal mucosa and increased AOPPs in serum, MDA and protein carbonyl in liver, MDA and AOPPs in jejunal mucosa $(\mathrm{p}<0.05)$.

Conclusion: Protein oxidation of SPI can be induced by heat and soybean oil and oxidized protein resulted in redox imbalance in broilers at an early age.

Keywords: Protein Oxidation; Broiler; Redox Status; Antioxidant Capacity; Soy Protein Isolate

\section{INTRODUCTION}

Dietary protein is the most important component of animal feed and its quality is highly associated with animal health. However, proteins are often exposed to oxidants or oxidizing conditions during processing and storage, and are vulnerable to oxidative modification [1]. Protein oxidation is the covalent modification of a protein induced directly by reactive oxygen species or indirectly by reaction with the secondary by-products of oxidative stress [2]. Researches concentrating on protein oxidation showed that protein oxidation could be induced by heat treatment and lipid in different proteins in vitro [3,4]. Protein oxidation can lead to multiple structural changes such as oxidation of side chains of specific amino acid residues or peptide chains, resulting in a decrease in nutritional value of protein $[5,6]$.

Previously, research on protein oxidation mainly focused on the food industry whereas little information is available concerning protein oxidation in the feed industry. Soybean meal is the 
most important protein resource used in animal diets. Heating is always essential during soybean meal processing [7], where protein oxidation occurs inevitably. Moreover, commercial soybean meal for animal feed still contains approximately $1 \%$ to $2 \%$ ether extract [8]. Although the residual lipid content in soybean meal is low, it may aggravate protein oxidation in soybean meal. However, it is difficult to study the effect of lipid on protein oxidation in soybean meal due to its complex components [8]. Soy protein isolate (SPI) is often used in protein oxidation studies mainly because of its relatively simple components. Our previous study has demonstrated that the solubility and digestibility of SPI were negatively affected by heat treatment and soybean oil, and that oxidized protein decreased growth performance and digestive function of broilers at an early age [9]. Moreover, some studies reported that oxidized protein could induce redox imbalance in mice [10], whereas no report has concentrated on redox status of broilers fed oxidized protein. Therefore, the objective of the study was to evaluate protein oxidation of SPI as affected by heat treatment and soybean oil inclusion in vitro and the effect of oxidized protein on redox status of broilers at early age.

\section{MATERIALS AND METHODS}

\section{Materials and chemicals}

SPI was purchased from Sun-Green Biotech Co., Ltd. (Jiangsu, China). Analyzed moisture, crude protein, ether extract and ash contents in the SPI were 58.0, 859.1, 4.5, and $49.1 \mathrm{~g} / \mathrm{kg}$, respectively. Soybean oil, devoid of any additives, was obtained from COFCO East China Sea Grain and Oil Industrial Co., Ltd. (Jiangsu, China). The 5,5'-dithiobis (2-nitrobenzoate) (DTNB) and 2,4,6-trinitrobenzenesulfonic acid were purchased from Sigma Chemical Co. (St. Louis, MO, USA). All other chemicals used in the experiment were of analytical grade.

\section{Modification of soy protein isolate with heat and soybean oil} SPI mixed with soybean oil ( $1 \%$ or $2 \%$ ) was prepared by a stirring machine at room temperature, referred to as SPIO1 and SPIO2, respectively. The mixture was then placed on glass plates and dry heated in an oven at $100^{\circ} \mathrm{C}$ for $1,2,4$, and $8 \mathrm{~h}$, respectively, airdried, and stored at $4^{\circ} \mathrm{C}$, according to the previously published methods [10]. For comparison purposes, SPI alone was treated following the procedures described above. Samples were defatted with hexane before analysis.

\section{Measurement of the oxidative markers of heated soy protein isolate}

Protein carbonyl content was measured by the reaction with 2,4dinitrophenylhydrazine according to the method of Huang et al [11]. Briefly, the samples were suspended in deionized water by stirring with a magnetic stirrer and the supernatant was collected. The supernatant was then mixed with 2,4-dinitrophenylhydrazine solution in a tube and incubated at $20^{\circ} \mathrm{C}$ for $2 \mathrm{~h}$. After that, tri- chloroacetic acid was added to the tube, the supernatant was discarded and the precipitate was washed three times with ethyl acetate solution. The protein, free of unreacted reagent, was suspended in guanidine hydrochloride solution and the absorbance at $367 \mathrm{~nm}$ was corrected for the absorbance in the $\mathrm{HCl}$ blank. The results were expressed as nmoles of carbonyl groups per milligram of soluble protein with a molar extinction coefficient of $22,000 \mathrm{~L} /(\mathrm{mol} \cdot \mathrm{cm})$. Contents of free sulfhydryl and total sulfhydryl in SPI were determined using Ellman's procedure modified by Huang et al [11]. In brief, the samples were suspended in phosphate buffer by stirring with a magnetic stirrer and the supernatant was collected. For free sulfhydryl determinations, the supernatant was reacted with DTNB reagent and centrifuged and the absorbance was measured at $412 \mathrm{~nm}$. For total sulfhydryl determinations, 2-mercaptoethanol and Urea-GuHCl were added to the protein solution and the mixture was incubated for $1 \mathrm{~h}$ at $25^{\circ} \mathrm{C}$. Then, trichloroacetic acid was added in the tube for an additional $1 \mathrm{~h}$ incubation and centrifuged. The precipitate was twice resuspended in trichloroacetic acid and centrifuged to remove 2mercaptoethanol. After that, the precipitate was dissolved in phosphate buffer with ethylenediaminetetraacetic acid and sodium dodecyl sulfate and the color was developed with $0.08 \mathrm{~mL}$ of Ellman's reagent. Absorbance was measured at $412 \mathrm{~nm}$ vs reagent blanks. The nmoles of sulfhydryl per milligram soluble protein were calculated by using the extinction coefficient of $13,600 \mathrm{~L} /(\mathrm{mol} \cdot \mathrm{cm})$. Soluble protein concentration was evaluated by the bicinchoninic acid method with bovine serum albumin as the standard (Nanjing Jiancheng Bioengineering Institute, Nanjing, China).

\section{Amino acid analyses}

Amino acids in SPI, SPIO1, and SPIO2 heated for 0, 2, 4, and $8 \mathrm{~h}$ were determined with an amino acid analyzer (Hitachi L-8900, Hitachi, Tokyo, Japan) after hydrolysis with $6 \mathrm{~mol} / \mathrm{L}$ of $\mathrm{HCl}$ at $110^{\circ} \mathrm{C}$ for $24 \mathrm{~h} \mathrm{[12].}$

\section{Animals and experimental design}

The experimental design and procedures involving animals were approved by the Animal Care and Use Committee of Nanjing Agricultural University.

A total of two hundred and sixteen 1-day-old Arbor Acres broilers were obtained from a commercial hatchery (Hewei, Anhui, China) and randomly divided into 3 groups with 6 replicates of 12 birds for a 21-d feeding trial. Birds were fed a basal diet (CON), $8 \mathrm{~h}$ heat-oxidized SPI diet (HSPI) or $8 \mathrm{~h}$ heat-oxidized mixture of SPI and 2\% soybean oil diet (HSPIO), respectively. The experimental diets were formulated according to the NRC (1994) nutrient requirements of the broiler. Ingredient composition and nutrient levels of the experimental diets are shown in Table 1.

All birds were housed in an environmentally controlled room. The temperature was maintained at $32^{\circ} \mathrm{C}$ from $\mathrm{d} 1$ to 7 , which 
Table 1. Ingredient composition and nutrient levels of the experimental diets (\%, airdried basis)

\begin{tabular}{lccc}
\hline \multirow{2}{*}{ Item } & \multicolumn{3}{c}{ Content $^{1)}$} \\
\cline { 2 - 4 } & CON & HSPI & HSPIO \\
\hline Corn & 77.97 & 77.97 & 77.97 \\
Soy protein isolate & 16.66 & - & - \\
Heat-oxidized soy protein isolate & - & 16.66 & - \\
Soybean oil & 0.34 & 0.34 & - \\
Heat-oxidized mixture of SPI & - & - & 17.00 \\
$\quad$ and 2\% soybean oil & & & \\
Limestone & 1.40 & 1.40 & 1.40 \\
Dicalcium phosphate & 1.95 & 1.95 & 1.95 \\
Sodium chloride & 0.30 & 0.30 & 0.30 \\
L-lysine & 0.20 & 0.20 & 0.20 \\
DL-methionine & 0.18 & 0.18 & 0.18 \\
Premix & 1.00 & 1.00 & 1.00 \\
Calculated nutrient levels ${ }^{2)}$ & & & \\
$\quad$ ME (MJ/kg) & 13.10 & 13.10 & 13.10 \\
CP & 21.11 & 20.93 & 21.08 \\
Calcium & 0.97 & 0.97 & 0.97 \\
Available phosphorus & 0.46 & 0.46 & 0.46 \\
Lysine & 1.21 & 1.17 & 1.17 \\
Methionine & 0.54 & 0.53 & 0.52 \\
\hline SPI soy pron & &
\end{tabular}

$\mathrm{SPI}$, soy protein isolate; $\mathrm{ME}$, metabolizable energy; $\mathrm{CP}$, crude protein.

1) CON, basal diet; HSPI, $8 \mathrm{~h}$ heat-oxidized SPI diet; HSPIO, $8 \mathrm{~h}$ heat-oxidized mixture of SPI and $2 \%$ soybean oil diet.

2) Premix provided per kilogram of diet: transretinyl acetate, $24 \mathrm{mg}$; cholecalciferol, $6 \mathrm{mg}$; all-rac- $\alpha$-tocopherol acetate, $20 \mathrm{mg}$; menadione, $1.3 \mathrm{mg}$; thiamin, $2.2 \mathrm{mg}$; riboflavin, $8 \mathrm{mg}$; nicotinamide, $40 \mathrm{mg}$; choline chloride, $400 \mathrm{mg}$; calcium pantothenate, $10 \mathrm{mg}$; pyridoxine $\cdot \mathrm{HCl}, 4 \mathrm{mg}$; biotin, $0.04 \mathrm{mg}$; folic acid, $1 \mathrm{mg}$; vitamin $\mathrm{B}_{12}$ (cobalamin), $0.013 \mathrm{mg}$; Fe (from ferrous sulfate), $80 \mathrm{mg}$; Cu (from copper sulfate), $7.5 \mathrm{mg} ; \mathrm{Mn}$ (from manganese sulfate), $110 \mathrm{mg} ; \mathrm{Zn}$ (from zinc oxide), $65 \mathrm{mg}$; ( (from calcium iodate), 1.1 $\mathrm{mg}$; Se (from sodium selenite), $0.3 \mathrm{mg}$.

${ }^{3)}$ Calculated value based on the analyzed data of SPI except for ME, calcium and available phosphorus.

was then gradually reduced to $26^{\circ} \mathrm{C}$ at the rate of $3^{\circ} \mathrm{C}$ per week and was maintained at this temperature to the end of the experiment. Overhead light was provided continuously for the entire period of the experiment. Birds were allowed ad libitum access to mash feed and water. At 21 day of age, birds were weighed after feed deprivation for $12 \mathrm{~h}$ and feed intake was recorded by replicate (cage) to calculate average daily feed intake, average daily gain (ADG), and feed conversion ratio (FCR).

\section{Sample collection}

At $\mathrm{d} 21$, one bird from each replicate was randomly selected. Blood samples (around $5 \mathrm{~mL}$ each) were collected from the wing vein and centrifuged at $3,000 \times \mathrm{g}$ for $15 \mathrm{~min}$ at $4^{\circ} \mathrm{C}$ to separate serum, which was stored at $-20^{\circ} \mathrm{C}$ for further analysis. After that, birds were euthanized by cervical dislocation and necropsied immediately. The liver, duodenal mucosa and jejunal mucosa samples were collected into plastic vials and stored at $-20^{\circ} \mathrm{C}$ for further analysis.

\section{Assay of antioxidant indices and oxidation products}

Serum, liver, duodenal mucosa and jejunal mucosa samples were analyzed for total superoxide dismutase (T-SOD), glutathione peroxidase (GSH-Px), catalase (CAT) activities and glutathione (GSH) content using commercial kits (Nanjing Jiancheng Bioengineering Institute, Nanjing, China) according to the manufacturer's instructions. Briefly, SOD enzyme was measured by xanthine oxidase method and one unit of SOD was defined as the amount of SOD required to produce $50 \%$ inhibition of the rate of nitrite production at $37^{\circ} \mathrm{C}$. GSH-Px activity was measured by dithio-nitro benzene method and one unit of GSH-Px activity was defined as the amount of enzyme that would catalyze the conversion of $1 \mu \mathrm{mol} / \mathrm{L}$ of GSH to oxidized $\mathrm{GSH}$ at $37^{\circ} \mathrm{C}$ in $5 \mathrm{~min}$. CAT enzyme was determined by the decomposition of hydrogen peroxide and one unit of CAT activity was defined as the amount of enzyme that would decompose $1 \mu \mathrm{mol}$ hydrogen peroxide per second. The amount of GSH in the samples was determined by using DTNB method. Hydroxyl radical scavenging capacity and superoxide anion radical scavenging capacity of samples were determined according to the method of Zhang et al [13]. Oxidation products of the samples were analyzed for malondialdehyde (MDA), total sulfhydryl, protein carbonyl and advanced oxidation protein products (AOPPs) content. The content of MDA was determined by following the thiobarbituric acid method as described by Placer et al [14]. Total sulfhydryl and protein carbonyl content were measured by the reaction with DTNB or 2,4dinitrophenylhydrazine according to the method of Huang et al [11], respectively. The content of AOPPs was measured by spectrophotometry according to the method of Witko-Sarsat et al [15]. Protein content of each sample was evaluated by the bicinchoninic acid method with bovine serum albumin as the standard (Nanjing Jiancheng Bioengineering Institute, Nanjing, China).

\section{Statistical analysis}

Data were analyzed by one-way analysis of variance (with Duncan multiple range test for post hoc comparison). SPSS statistical software (ver.16.0 for Windows, SPSS Inc., Chicago, IL, USA) was used for all statistic analysis. Data were considered significant at $p<0.05$, and $p$ values between 0.05 and 0.1 were considered as a trend. The means and total standard error of means are presented.

\section{RESULTS}

\section{Characterization of the oxidative markers of heated soy protein isolate}

Heating at $100^{\circ} \mathrm{C}$ increased protein carbonyl content of SPI in all treatments $(\mathrm{p}<0.05$, Table 2$)$. Higher carbonyl content was observed in SPIO2 than in SPI at $8 \mathrm{~h}$ of heating $(\mathrm{p}<0.05)$. Both free sulfhydryl and total sulfhydryl contents gradually declined during heating $(\mathrm{p}<0.05)$. Soybean oil did not affect the content of free sulfhydryl or total sulfhydryl during heating $(\mathrm{p}>0.05)$. 
Table 2. Protein carbonyl, free and total sulfhydryl group content of SPI heated with different soybean oil contents at $100^{\circ} \mathrm{C}(\mathrm{nmol} / \mathrm{mg}$ protein)

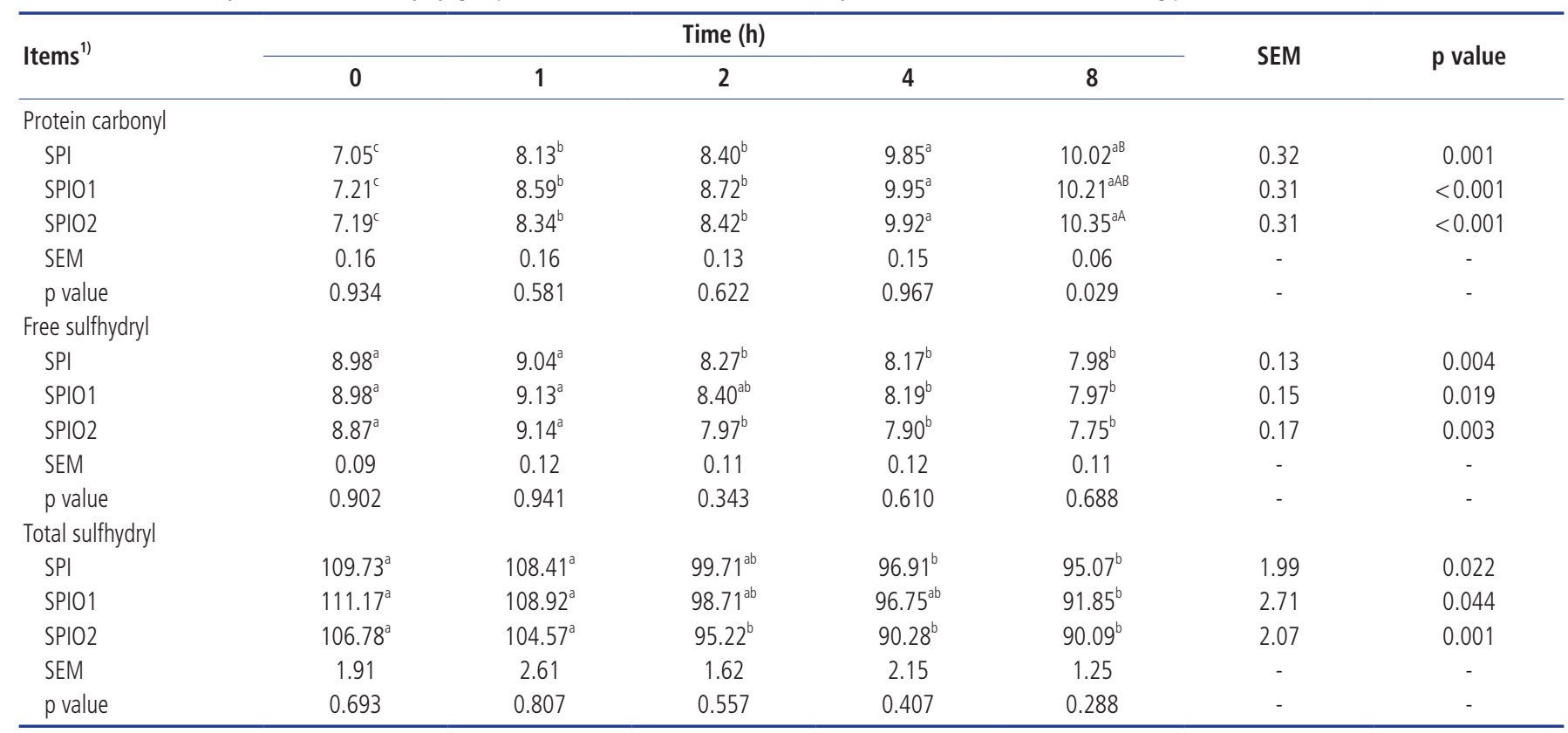

SEM, standard error of means.

1) SPI, soy protein isolate; SPI01, SPI mixed with 1\% soybean oil; SPIO2, SPI mixed with 2\% soybean oil.

Different letters in the same row $(a-c)$ or the same column $(A, B)$ indicate significant differences $(p<0.05)$.

\section{Amino acids analyses}

As shown in Table 3, decreased threonine, methionine and lysine were observed in all treatments as heating time increased $(\mathrm{p}<0.1)$. A trend to decreased methionine was observed in SPIO2 at 8 $h$ of heating $(p=0.067)$. No differences were observed in other

Table 3. Threonine, methionine and lysine of SPI heated with different soybean oil contents at $100^{\circ} \mathrm{C}(\%$, dry matter basis)

\begin{tabular}{|c|c|c|c|c|c|c|}
\hline \multirow{2}{*}{ |tems ${ }^{1)}$} & \multicolumn{4}{|c|}{ Time (h) } & \multirow{2}{*}{ SEM } & \multirow{2}{*}{$p$ value } \\
\hline & 0 & 2 & 4 & 8 & & \\
\hline \multicolumn{7}{|l|}{ Threonine } \\
\hline SPI & 3.87 & 3.80 & 3.79 & 3.77 & 0.02 & 0.078 \\
\hline SPI01 & 3.84 & 3.82 & 3.82 & 3.72 & 0.02 & 0.071 \\
\hline SPIO2 & 3.85 & 3.75 & 3.76 & 3.70 & 0.02 & 0.065 \\
\hline SEM & 0.01 & 0.02 & 0.01 & 0.02 & - & - \\
\hline p value & 0.736 & 0.312 & 0.125 & 0.478 & - & - \\
\hline \multicolumn{7}{|l|}{ Methionine } \\
\hline SPI & 1.24 & 1.20 & 1.19 & 1.18 & 0.01 & 0.090 \\
\hline SPI01 & 1.23 & 1.20 & 1.17 & 1.16 & 0.01 & 0.066 \\
\hline SPIO2 & 1.23 & 1.18 & 1.15 & 1.14 & 0.01 & 0.061 \\
\hline SEM & 0.01 & 0.01 & 0.02 & 0.01 & - & - \\
\hline$p$ value & 0.635 & 0.230 & 0.626 & 0.067 & - & - \\
\hline \multicolumn{7}{|l|}{ Lysine } \\
\hline SPI & 5.68 & 5.44 & 5.41 & 5.38 & 0.05 & 0.055 \\
\hline SPI01 & 5.76 & 5.56 & 5.72 & 5.32 & 0.07 & 0.053 \\
\hline SPIO2 & 5.77 & 5.59 & 5.48 & 5.46 & 0.05 & 0.076 \\
\hline SEM & 0.04 & 0.06 & 0.04 & 0.04 & - & - \\
\hline$p$ value & 0.973 & 0.961 & 0.955 & 0.726 & - & - \\
\hline
\end{tabular}

SEM, standard error of means.

1) SPI, soy protein isolate; SPI01, SPI mixed with $1 \%$ soybean oil; SPIO2, SPI mixed with $2 \%$ soybean oil. amino acids ( $\mathrm{p}>0.05$, data not shown).

\section{Growth performance}

Broilers fed the HSPI and HSPIO exhibited decreased ADG as compared with that of the $\mathrm{CON}$ ( $\mathrm{p}<0.05$, Table 4 ). A tendency for reduced FCR was observed in broilers fed the HSPI and HSPIO $(\mathrm{p}=0.068)$.

\section{Antioxidant indices and oxidation products content} Decreased GSH and increased MDA and protein carbonyl content were observed in serum of broilers fed HSPI and HSPIO $(p<0.05$, Table 5$)$. HSPIO decreased GSH-Px activity and increased AOPPs content in serum of broilers as compared with the CON $(p<0.05)$. GSH content in liver of broilers fed the HSPIO was lower than that of other groups ( $<0.05$, Table 6 ). Broilers fed HSPI and HSPIO had decreased CAT activity and total sul-

Table 4. Growth performance of broilers fed basal diet, heat-oxidized SPI diet or heat-oxidized mixture of SPI and 2\% soybean oil diet

\begin{tabular}{lccccc}
\hline \multirow{2}{*}{ Items } & \multicolumn{3}{c}{ Treatment $^{\text {1) }}$} & \multirow{2}{*}{ SEM } & p value \\
\cline { 2 - 4 } & CON & HSPI & HSPIO & & \\
\hline ADG (g/d) & $26.21^{\mathrm{a}}$ & $24.82^{\mathrm{b}}$ & $24.09^{\mathrm{b}}$ & 0.27 & 0.001 \\
ADFI (g/d) & 39.23 & 37.97 & 38.12 & 0.39 & 0.378 \\
FCR (g:g) & 1.50 & 1.53 & 1.58 & 0.02 & 0.068 \\
\hline
\end{tabular}

SPI, soy protein isolate; $S E M$, standard error of means; $A D G$, average daily gain; $A D F I$, average daily feed intake; $F C R$, feed conversion ratio.

1) CON, basal diet; HSPI, $8 \mathrm{~h}$ heat-oxidized SPI diet; HSPIO, $8 \mathrm{~h}$ heat-oxidized mixture of SPI and $2 \%$ soybean oil diet.

Different letters in the same row $(a, b)$ indicate significant differences $(p<0.05)$. 
Table 5. Serum antioxidant indices and oxidation products contents of broilers fed basal diet, heat-oxidized SPI diet or heat-oxidized mixture of SPI and 2\% soybean oil diet ${ }^{1)}$

\begin{tabular}{|c|c|c|c|c|c|}
\hline \multirow{2}{*}{ Items } & \multicolumn{3}{|c|}{ Treatment $^{2)}$} & \multirow{2}{*}{ SEM } & \multirow{2}{*}{$\mathrm{p}$ value } \\
\hline & CON & HSPI & HSPIO & & \\
\hline T-SOD (U/mL) & 212.88 & 204.81 & 167.58 & 9.18 & 0.070 \\
\hline GSH-Px (U/mL) & $997.38^{\mathrm{a}}$ & $916.98^{\mathrm{ab}}$ & $866.45^{b}$ & 21.04 & 0.026 \\
\hline CAT (U/mL) & 0.65 & 0.66 & 0.60 & 0.05 & 0.917 \\
\hline $\mathrm{GSH}(\mu \mathrm{mol} / \mathrm{mL})$ & $30.14^{\mathrm{a}}$ & $17.98^{b}$ & $15.59^{b}$ & 2.24 & 0.008 \\
\hline Hydroxyl radical scavenging capacity (U/mL) & 381.37 & 359.31 & 360.65 & 11.10 & 0.688 \\
\hline Superoxide anion radical scavenging capacity (U/L) & 121.79 & 113.04 & 118.12 & 5.31 & 0.824 \\
\hline $\mathrm{MDA}(\mathrm{nmol} / \mathrm{mL})$ & $3.80^{\mathrm{b}}$ & $4.28^{\mathrm{a}}$ & $4.46^{\mathrm{a}}$ & 0.11 & 0.020 \\
\hline Total sulfhydryl ( $\mu \mathrm{mol} / \mathrm{L})$ & 255.33 & 250.08 & 231.87 & 6.73 & 0.349 \\
\hline Protein carbonyl (nmol/mg protein) & $1.38^{\mathrm{b}}$ & $2.46^{\mathrm{a}}$ & $2.77^{\mathrm{a}}$ & 0.18 & 0.001 \\
\hline AOPPs (pmol/L) & $229.97^{b}$ & $251.24^{\mathrm{ab}}$ & $259.45^{\mathrm{a}}$ & 4.91 & 0.029 \\
\hline
\end{tabular}

SPI, soy protein isolate; SEM, standard error of means; T-SOD, total superoxide dismutase; GSH-Px, glutathione peroxidase; CAT, catalase; GSH, glutathione; MDA, malondialdehyde; AOPPS, advanced oxidation protein products.

1) Results are the mean of 6 replicates $(n=6)$ with 12 chickens/replicate.

${ }^{2)} \mathrm{CON}$, basal diet; HSPI, $8 \mathrm{~h}$ heat-oxidized SPI diet; HSPIO, $8 \mathrm{~h}$ heat-oxidized mixture of SPI and $2 \%$ soybean oil diet.

Different letters in the same row $(a, b)$ indicate significant differences $(p<0.05)$.

fhydryl content and increased AOPPs content in liver $(\mathrm{p}<0.05)$. Additionally, HSPIO decreased hydroxyl radical scavenging capacity and increased MDA and protein carbonyl content in liver as compared with the CON $(\mathrm{p}<0.05)$. Duodenal mucosa GSH content in broilers fed HSPIO was lower than that of other groups ( $\mathrm{p}<0.05$, Table 7 ). Broilers fed HSPIO had decreased GSHPx activity and superoxide anion radical scavenging capacity and increased AOPPs content in jejunal mucosa $(\mathrm{p}<0.05$, Table 8$)$. As compared with the CON, broilers fed HSPIO exhibited increased MDA content in jejunal mucosa, and the same effect was also observed in protein carbonyl content of broilers fed HSPI and HSPIO $(\mathrm{p}<0.05)$.

\section{DISCUSSION}

Formation of protein bound carbonyls is one of the most salient changes in oxidized protein and therefore the concentration of protein bound carbonyls is considered to be indicative for the degree of protein oxidation [16]. This study demonstrated that protein carbonyl content of SPI increased as heating time increased. Our findings were similar to Tang et al [10], who also reported that heat treatment at $100^{\circ} \mathrm{C}$ caused a significant increase in protein carbonyl of SPI. It was demonstrated that carbonyl groups could be introduced into protein by oxidation of amino acid residues, such as threonine, cystenine, lysine, and histidine $[17,18]$. As a result, oxidation of amino acids might result in lots of protein carbonyls. Compared with the SPI, addition of $2 \%$ soybean oil significantly increased protein carbonyl content in SPI after $8 \mathrm{~h}$ of heating. Cucu et al [19] also found that the protein carbonyl content of whey protein was enhanced by the presence of lipid. During heating, lipid peroxidation might occur in soybean oil and thus lipid hydroperoxides or advanced lipoxidation

Table 6. Liver antioxidant indices and oxidation products contents of broilers fed basal diet, heat-oxidized SPI diet or heat-oxidized mixture of SPI and 2\% soybean oil diet ${ }^{1)}$

\begin{tabular}{|c|c|c|c|c|c|}
\hline \multirow{2}{*}{ Items } & \multicolumn{3}{|c|}{ Treatment $^{2)}$} & \multirow{2}{*}{ SEM } & \multirow{2}{*}{$\mathrm{p}$ value } \\
\hline & CON & HSPI & HSPIO & & \\
\hline T-SOD (U/mg protein) & 62.05 & 67.01 & 62.85 & 1.69 & 0.465 \\
\hline GSH-Px (U/mg protein) & 36.78 & 44.86 & 35.50 & 1.83 & 0.081 \\
\hline CAT (U/mg protein) & $5.43^{\mathrm{a}}$ & $3.47^{b}$ & $3.68^{b}$ & 0.33 & 0.018 \\
\hline GSH ( $\mu$ mol/g protein) & $48.15^{\mathrm{a}}$ & $43.07^{\mathrm{a}}$ & $33.96^{\mathrm{b}}$ & 2.07 & 0.005 \\
\hline Hydroxyl radical scavenging capacity (U/mg protein) & $3,511.90^{\mathrm{a}}$ & $3,006.21^{\mathrm{ab}}$ & $2,576.19^{b}$ & 144.20 & 0.020 \\
\hline Superoxide anion radical scavenging capacity (U/g protein) & 132.96 & 123.31 & 126.41 & 4.67 & 0.739 \\
\hline $\mathrm{MDA}$ (nmol/mg protein) & $0.48^{\mathrm{b}}$ & $0.66^{\mathrm{ab}}$ & $0.71^{\mathrm{a}}$ & 0.04 & 0.043 \\
\hline Total sulfhydryl (umol/g protein) & $161.05^{\mathrm{a}}$ & $132.30^{\mathrm{b}}$ & $135.12^{b}$ & 4.45 & 0.008 \\
\hline Protein carbonyl (nmol/mg protein) & $3.69^{b}$ & $3.94^{\mathrm{ab}}$ & $4.62^{\mathrm{a}}$ & 0.16 & 0.033 \\
\hline AOPPs (pmol/g protein) & $286.46^{b}$ & $383.76^{\mathrm{a}}$ & $355.85^{\mathrm{a}}$ & 15.55 & 0.025 \\
\hline
\end{tabular}

SPI, soy protein isolate; SEM, standard error of means; T-SOD, total superoxide dismutase; GSH-Px, glutathione peroxidase; CAT, catalase; GSH, glutathione; MDA, malondialdehyde; AOPPs, advanced oxidation protein products.

${ }^{1)}$ Results are the mean of 6 replicates $(n=6)$ with 12 chickens/replicate.

${ }^{2)}$ CON, basal diet; HSPI, $8 \mathrm{~h}$ heat-oxidized SPI diet; HSPIO, $8 \mathrm{~h}$ heat-oxidized mixture of SPI and 2\% soybean oil diet. Different letters in the same row (a, b) indicate significant differences $(p<0.05)$. 
Table 7. Duodenal mucosa antioxidant indices and oxidation products contents of broilers fed basal diet, heat-oxidized SPI diet or heat-oxidized mixture of SPI and 2\% soybean oil $\operatorname{diet}^{1)}$

\begin{tabular}{|c|c|c|c|c|c|}
\hline \multirow{2}{*}{ Items } & \multicolumn{3}{|c|}{ Treatment $^{2)}$} & \multirow{2}{*}{ SEM } & \multirow{2}{*}{$\mathrm{p}$ value } \\
\hline & CON & HSPI & HSPIO & & \\
\hline T-SOD (U/mg protein) & 76.94 & 76.55 & 69.44 & 2.18 & 0.302 \\
\hline GSH-Px (U/mg protein) & $23.58^{\mathrm{a}}$ & $25.42^{\mathrm{a}}$ & $14.78^{b}$ & 1.37 & $<0.001$ \\
\hline CAT (U/mg protein) & 1.62 & 1.54 & 1.68 & 0.10 & 0.878 \\
\hline GSH ( $\mu \mathrm{mol} / \mathrm{g}$ protein) & 97.42 & 97.41 & 78.19 & 4.06 & 0.068 \\
\hline Hydroxyl radical scavenging capacity (U/mg protein) & $4,099.32$ & $3,846.70$ & $3,704.64$ & 214.44 & 0.801 \\
\hline Superoxide anion radical scavenging capacity (U/g protein) & 142.14 & 158.94 & 153.69 & 4.09 & 0.295 \\
\hline MDA (nmol/mg protein) & 0.79 & 0.76 & 0.73 & 0.05 & 0.908 \\
\hline Total sulfhydryl ( $\mu \mathrm{mol} / \mathrm{g}$ protein) & 185.54 & 212.55 & 192.91 & 8.28 & 0.412 \\
\hline Protein carbonyl (nmol/mg protein) & 5.75 & 5.78 & 6.04 & 0.26 & 0.897 \\
\hline AOPPs (pmol/g protein) & 332.78 & 349.66 & 344.40 & 17.17 & 0.928 \\
\hline
\end{tabular}

SPI, soy protein isolate; SEM, standard error of means; T-SOD, total superoxide dismutase; GSH-Px, glutathione peroxidase; CAT, catalase; GSH, glutathione; MDA, malondialdehyde; AOPPs, advanced oxidation protein products.

1) Results are the mean of 6 replicates ( $n=6)$ with 12 chickens/replicate.

${ }^{2)}$ CON, basal diet; HSPI, $8 \mathrm{~h}$ heat-oxidized SPI diet; HSPIO, $8 \mathrm{~h}$ heat-oxidized mixture of SPI and $2 \%$ soybean oil diet.

Different letters in the same row $(a, b)$ indicate significant differences $(p<0.05)$.

end products could form [20]. These products might be able to react with primary amino groups of protein and hence introduce carbonyl groups into protein $[17,21]$. It was reported that the protein oxidation led, in the first place, to the modification of the thiol groups [4]. However, the carbonyl contents does not reflect oxidation state of sulfur-containing amino acid such as cysteine residues. Thus, protein sulfhydryl content was assayed in this study. Protein sulfhydryl can be oxidized to reversible form (protein disulfide) or irreversible form (sulfinic and sulphonic acid) in different oxidative environments $[22,23]$. The simultaneous decrease of free sulfhydryl and total sulfhydryl in this study could be attributed to the formation of sulphur oxidation products other than disulfide bonds. Soybean oil did not affect protein sulfhydryl content among treatments. However, our findings were not consistent with Boatright and Hettiarachchy [3], who reported that adding lipid (3.3\% to 5.7\%) during SPI processing led to a decline in the sulfhydryl content. This inconsistent result obtained might result from the different lipid content between the experiments.

Oxygen radicals and other activated oxygen species could cause modifications of the amino acids of protein [24]. Previous studies had demonstrated that methionine, cysteine, lysine and histidine were sensitive to oxidation [4]. In the current investigation, trends to decreased levels of threonine, methionine and lysine in all treatments and methionine in SPIO2 at $8 \mathrm{~h}$ heating were observed. These results are consistent with the increased protein carbonyl and decreased protein sulfhydryl content as discussed above.

Current study showed that dietary oxidized protein resulted in inferior growth performance of broilers, which was likely the result from the imbalanced redox status of broilers fed oxidized protein as discussed in the following. Antioxidant enzyme system is a defense system against reactive oxygen species mediating

Table 8. Jejunal mucosa antioxidant indices and oxidation products content of broilers fed basal diet, heat-oxidized SPI diet or heat-oxidized mixture of SPI and 2\% soybean oil diet")

\begin{tabular}{|c|c|c|c|c|c|}
\hline \multirow{2}{*}{ Items } & \multicolumn{3}{|c|}{ Treatment $^{2)}$} & \multirow{2}{*}{ SEM } & \multirow{2}{*}{$\mathrm{p}$ value } \\
\hline & $\mathrm{CON}$ & HSPI & HSPIO & & \\
\hline T-SOD (U/mg protein) & 27.01 & 29.51 & 25.32 & 1.19 & 0.376 \\
\hline GSH-Px (U/mg protein) & $11.38^{\mathrm{a}}$ & $10.20^{\mathrm{a}}$ & $4.28^{b}$ & 0.86 & $<0.001$ \\
\hline CAT (U/mg protein) & 2.73 & 2.79 & 2.47 & 0.17 & 0.741 \\
\hline GSH ( $\mu \mathrm{mol} / \mathrm{g}$ protein) & 46.60 & 46.64 & 42.55 & 1.97 & 0.692 \\
\hline Hydroxyl radical scavenging capacity (U/mg protein) & 836.92 & 846.57 & 814.99 & 42.67 & 0.960 \\
\hline Superoxide anion radical scavenging capacity (U/g protein) & $108.97^{\mathrm{a}}$ & $107.80^{\mathrm{a}}$ & $86.07^{b}$ & 4.20 & 0.028 \\
\hline MDA (nmol/mg protein) & $0.54^{b}$ & $0.62^{\mathrm{ab}}$ & $0.75^{\mathrm{a}}$ & 0.03 & 0.017 \\
\hline Total sulfhydryl ( $\mu$ mol/g protein) & 148.92 & 145.23 & 146.89 & 4.94 & 0.959 \\
\hline Protein carbonyl (nmol/mg protein) & $7.03^{b}$ & $7.89^{\mathrm{a}}$ & $7.96^{\mathrm{a}}$ & 0.13 & $<0.001$ \\
\hline AOPPs (pmol/g protein) & $1,052.19^{b}$ & $1,108.50^{b}$ & $1,238.55^{\mathrm{a}}$ & 28.67 & 0.017 \\
\hline
\end{tabular}

SPI, soy protein isolate; SEM, standard error of means; T-SOD, total superoxide dismutase; GSH-Px, glutathione peroxidase; CAT, catalase; GSH, glutathione; MDA, malondialdehyde; AOPPs, advanced oxidation protein products.

1) Results are the mean of 6 replicates $(n=6)$ with 12 chickens/replicate.

2) CON, basal diet; HSPI, $8 \mathrm{~h}$ heat-oxidized SPI diet; HSPIO, $8 \mathrm{~h}$ heat-oxidized mixture of SPI and $2 \%$ soybean oil diet.

Different letters in the same row $(a, b)$ indicate significant differences $(p<0.05)$. 
damage in the body, including T-SOD, GSH-Px, and CAT [25]. GSH provides a substrate for GSH-Px and can also sometimes 'repair' radicals resulting from an attack by $\mathrm{OH}$. [26]. In the current study, supplementation of HSPI, especially HSPIO, decreased these antioxidant enzyme activities or GSH content in serum, liver, duodenal mucosa or jejunal mucosa, implying that oxidized protein depressed the development of the antioxidant defense system in liver and intestinal tract in broilers. It has reported that oxidized protein could stimulate reactive oxygen species generation in mice because of altered physicochemical properties in soy protein [10]. Moreover, research also reported that accumulation of oxidative products could further induce production of reactive oxygen species [27]. Thus, oxidized protein might increase the level of reactive oxygen species and cause oxidative stress of broilers and then result in an inhibition of antioxidant capacity. Hydroxyl radical is well-known to be the most reactive of all the reduced forms of dioxygen [28]. Superoxide anion radical is one of the most representative free radicals, and its negative effects can be magnified because it produces other kinds of celldamaging free radicals and oxidizing agents [29]. Decreased free radical scavenging capacity in liver and jejunal mucosa of broilers fed HSPIO was observed, which might result from the compromised antioxidant enzyme activity as discussed above. MDA is widely used as a biomarker for oxidative deterioration of lipid. Protein carbonyls and AOPPs content are compounds derived from protein oxidation. The amount of these compounds was a response of oxidative extent of lipids and proteins. Increase of these oxidation products in serum, liver and jejunal mucosa was observed in broilers fed HSPI and the increases were higher in broilers fed HSPIO. Oxidative stress can stimulate the production of reactive oxygen species, induce lipid peroxidation, and cause protein damages [30]. Therefore, the accumulation of these oxidation compounds might result from the oxidative stress induced by oxidized protein in broilers.

In conclusion, this study indicated that protein oxidation of SPI could be induced by heat and soybean oil. Oxidized protein decreased growth performance, depressed antioxidant capacity and increased oxidation products and resulted in redox imbalance of broilers.

\section{CONFLICT OF INTEREST}

We certify that there is no conflict of interest with any financial organization regarding the material discussed in the manuscript.

\section{ACKNOWLEDGMENTS}

We gratefully thank our labmates in the College of Animal Science and Technology of Nanjing Agricultural University for their assistant in this study.

\section{REFERENCES}

1. Wu W, Hou L, Zhang C, Kong X, Hua Y. Structural modification of soy protein by 13-hydroperoxyoctadecadienoic acid. Eur Food Res Technol 2009;229:771-8.

2. Shacter, E. Quantification and significance of protein oxidation in biological samples. Drug Metab Rev 2000;32:307-26.

3. Boatright WL, Hettiarachchy NS. Effect of lipids on soy protein isolate solubility. J Am Oil Chem Soc 1995;72:1439-44.

4. Cucu T, Devreese B, Kerkaert B, et al. A comparative study of lipid and hypochlorous acid induced oxidation of soybean proteins. LWTFood Sci Technol 2013;50:451-8.

5. Höhn A, König J, Grune T. Protein oxidation in aging and the removal of oxidized proteins. J Proteomics 2013;92:132-59.

6. Zhou F, Zhao M, Cui C, Sun W. Influence of linoleic acid-induced oxidative modifications on physicochemical changes and in vitro digestibility of porcine myofibrillar proteins. LWT-Food Sci Technol 2015;61:414-21.

7. Lusas EW, Riaz MN. Soy protein products: processing and use. J Nutr 1995;3:573S-80S.

8. Waller JC. Byproducts and unusual feedstuffs. Feedstuffs Reference Issue 2010;82:18-23.

9. Zhang X, Lu P, Xue W, et al. Digestive evaluation of soy isolate protein as affected by heat treatment and soy oil inclusion in broilers at an early age. Anim Sci J 2016;87:1291-7.

10. Tang X, Wu Q, Le G, Shi Y. Effects of heat treatment on structural modification and in vivo antioxidant capacity of soy protein. Nutrition 2012;28:1180-5.

11. Huang Y, Hua Y, Qiu A. Soybean protein aggregation induced by lipoxygenase catalyzed linoleic acid oxidation. Food Res Int 2006;39: 240-9.

12. Yin FG, Liu YL, Yin YL, et al. Dietary supplementation with Astragalus polysaccharide enhances ileal digestibilities and serum concentrations of amino acids in early weaned piglets. Amino Acids 2009;37:263-70.

13. Zhang J, Hu Z, Lu C, et al. Effect of various levels of dietary curcumin on meat quality and antioxidant profile of breast muscle in broilers. J Agric Food Chem 2015;63:3880-6.

14. Placer ZA, Cushman LL, Johnson BC. Estimation of product of lipid peroxidation (malonyl dialdehyde) in biochemical systems. Anal Biochem 1966;16:359-64.

15. Witko-Sarsat V, Friedlander M, Capeillere-Blandin C, et al. Advanced oxidation protein products as a novel marker of oxidative stress in uremia. Kidney Int 1996;49:1304-13.

16. Levine RL, Garland D, Oliver CN, et al. Determination of carbonyl content in oxidatively modified proteins. Methods Enzymol 1990;186: 464-78.

17. Berlett BS, Stadtman ER. Protein oxidation in aging, disease, and oxidative stress. J Biol Chem 1997;272:20313-6.

18. Wu W, Wu X, Hua Y. Structural modification of soy protein by the lipid peroxidation product acrolein. LWT-Food Sci Technol 2010;43: 133-40.

19. Cucu T, Devreese B, Mestdagh F, Kerkaert B, De Meulenaer B. Protein- 
lipid interactions during the incubation of whey proteins with autoxidizing lipids. Int Dairy J 2011;21:427-33.

20. Tironi VA, Tomás MC, Añón MC. Structural and functional changes in myofibrillar proteins of sea salmon (Pseudopercis semifasciata) by interaction with malonaldehyde (RI). J Food Sci 2002;67:930-5.

21. Wu W, Zhang C, Hua Y. Structural modification of soy protein by the lipid peroxidation product malondialdehyde. J Sci Food Agric 2009;89:1416-23.

22. Thomas JA, Mallis RJ. Aging and oxidation of reactive protein sulfhydryls. Exp Gerontol 2001;36:1519-26.

23. Eaton P. Protein thiol oxidation in health and disease: techniques for measuring disulfides and related modifications in complex protein mixtures. Free Radical Bio Med 2006;40:1889-99.

24. Davies KJA. Degradation of oxidized proteins by the 20 S proteasome. Biochimie 2001;83:301-10.

25. Matés JM, Pérez-Gómez C, Blanca M. Chemical and biological activity of free radical scavengers in allergic diseases. Clin Chim Acta 2000;296: 1-15.

26. Halliwell B, Gutteridge JMC. Free radicals in biology and medicine. USA: Oxford University Press; 2015.

27. Servettaz A, Guilpain P, Goulvestre C, et al. Radical oxygen species production induced by advanced oxidation protein products predicts clinical evolution and response to treatment in systemic sclerosis. Ann Rheum Dis 2007;66:1202-9.

28. Noda Y, Kaneyuki T, Mori A, Packer L. Antioxidant activities of pomegranate fruit extract and its anthocyanidins: delphinidin, cyanidin, and pelargonidin. J Agric Food Chem 2002;50:166-71.

29. Heo SJ, Park EJ, Lee KW, Jeon YJ. Antioxidant activities of enzymatic extracts from brown seaweeds. Bioresour Technol 2005;96:1613-23.

30. Dröge W. Free radicals in the physiological control of cell function. Physiol Rev 2002;82:47-95. 